\title{
Testing the Twin Deficits Hypothesis: Effect of Fiscal Balance on Current Account Balance-A Panel Analysis of Sub-Saharan Africa
}

\author{
Godson Korbla Aloryito, Bernardin Senadza, Edward Nketiah-Amponsah \\ Department of Economics, University of Ghana, Legon, Ghana \\ Email: godsonka@gmail.com,bsenadza@ug.edu.gh,enamponsah@ug.edu.gh
}

Received 13 July 2016; accepted 9 August 2016; published 12 August 2016

Copyright (C) 2016 by authors and Scientific Research Publishing Inc.

This work is licensed under the Creative Commons Attribution International License (CC BY).

http://creativecommons.org/licenses/by/4.0/

(c) (i) Open Access

\begin{abstract}
The twin deficits hypothesis holds if government's fiscal deficit, through its impact on national saving and consumption, leads to a deterioration of the current account. The fiscal and current account deficits of most countries in Sub-Saharan Africa (SSA) appear relatively large or have been widening over the past several years in the face of positive output growth and steady decline in inflation. Using data for 41 countries from 2000 to 2012, we test the twin deficits hypothesis for SSA. Applying the system Generalised Method of Moments (GMM) estimation technique, the major conclusion drawn from the results indicates that fiscal deficits tend to improve the current account and vice versa, thereby rejecting the twin deficits hypothesis in favor of the twin divergence proposition. The findings, nonetheless, have policy relevance for the region.
\end{abstract}

\section{Keywords}

Twin Deficits, Fiscal Deficit, Current Account Deficit, System GMM, Sub-Saharan Africa

\section{Introduction}

The twin deficits hypothesis holds if government's budget deficit, through its impact on national saving and consumption, leads to a deterioration of the current account [1]. According to the conventional twin deficits hypothesis, when government increases its fiscal deficits, for instance, by spending in excess of its tax revenue, then the decline in national saving calls for the country to typically borrow funds from abroad to finance the excess expenditure in order not to crowd out domestic private investment.

How to cite this paper: Aloryito, G.K., Senadza, B. and Nketiah-Amponsah, E. (2016) Testing the Twin Deficits Hypothesis: Effect of Fiscal Balance on Current Account Balance-A Panel Analysis of Sub-Saharan Africa. Modern Economy, 7, 945-954. http://dx.doi.org/10.4236/me.2016.79097 
The aftermath of recent developments in the global economy such as the global financial crisis of 2008 and 2009 and the debt crisis in the Eurozone in 2011 has re-ignited debates mostly among policy makers and economists in the developed economies particularly, about the twin-deficits hypothesis. Public sector profligacy in some economies, for example, in the post 2001 era in the United States is argued to have accounted for the accumulation of colossal global external imbalances, which possibly contributed to the genesis and severity of the financial and economic crisis of 2008-2009. Similarly, entering a hard-hitting economic downturn with a precarious budget balance obviously confines the scope for fiscal stimulus and can possibly lead to a Greek-like sovereign debt crisis [2].

The fiscal and current account deficits of most countries in Sub-Saharan Africa (SSA) appear relatively large or have been widening over the past several years in the face of positive output growth and steady decline in inflation [3]. For instance, real GDP growth for SSA has been positive and averaged more than 5 percent per annum over the past decade and inflation has generally been single digit (see Table 1). Yet, as Figure 1 shown, the current account balance and budget balance have been in deficit for the past decade and appear to be increasing in the last few years. Is the fiscal deficit responsible for the current account deficit in SSA in consonance with the twin deficits hypothesis?

The region's persistent negative fiscal and current account balances over the past few years which contrasts the positive outlook of other macroeconomic indicators such as real output growth and inflation rates over the same period require further scrutiny to ascertain whether or not there is a link between SSA's internal and external balances.

There are several studies on the twin deficits hypothesis using large panels of countries in the literature, the focus have been predominantly on developed economies (see for instance, [2] [4]-[7]) and a few on specific developing economies in Latin America, South-East Asia and Sub-Saharan Africa. Even in cross- country studies, Sub-Saharan African countries have not received fair coverage relative to their counterparts from other parts of

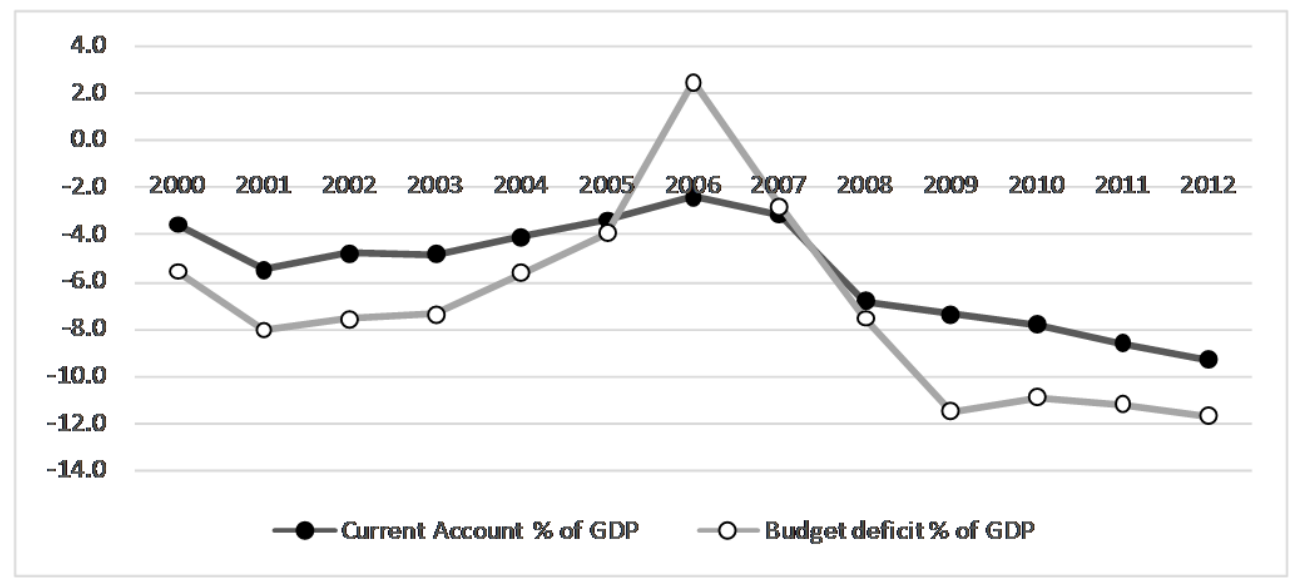

Figure 1. Current account and budget balances in SSA: 2000-2012. Source: By authors based on data from the IMF's WEO and the World Bank's WDI.

Table 1. Sub-Saharan Africa: Some macroeconomic indicators.

\begin{tabular}{|c|c|c|c|c|c|c|}
\hline Description & 2004-2008 & 2010 & 2011 & 2012 & 2013 & 2014 \\
\hline & \multicolumn{6}{|c|}{ (Percent change) (Projection) } \\
\hline Real GDP growth & 6.4 & 5.4 & 5.3 & 5.1 & 5.4 & 5.7 \\
\hline \multirow[t]{2}{*}{ Inflation, end of period } & 8.8 & 7.2 & 10.1 & 7.9 & 6.9 & 5.8 \\
\hline & \multicolumn{6}{|c|}{ (Percent of Regional GDP) } \\
\hline Fiscal balance & 1.9 & -3.9 & -1.3 & -1.7 & -2.7 & -2.8 \\
\hline Current account balance & 0.6 & -1.3 & -1.7 & -2.8 & -3.5 & -4.1 \\
\hline
\end{tabular}

Source: IMF-World Economic Outlook database, 2013. 
the world. Just a selected number of SSA countries are captured in such studies (see [8]-[11]). An SSA specific study therefore becomes imperative.

The empirical and theoretical literature does not have a common position on the twin-deficits hypothesis. [12] suggests that post-1990 data on fiscal and current account deficits for the largest industrial countries provide some support for the twin deficits hypothesis. Yet, there are noteworthy exceptions. For example, the improving U.S. fiscal accounts from 1992 to 2000 were associated with a worsening U.S. current account. The stability of Japan's current account surplus during the 1990s, even with the country's sharply declining fiscal condition, is another exception to the twin deficits hypothesis. In fact, Japan's experience in the 1990s is often cited as evidence that changes in private saving can offset changes in fiscal policy, leaving a country's current account balance largely unaffected [12]. These deliberations so suggest that there should be a significant link between the budget and current account deficits, then fiscal prescriptions could be used to deal with external imbalances, ceteris paribus.

Fiscal profligacy has been adduced as responsible for the current account problems of many developed economies according to some economists. The results of some empirical studies give credence to this position and thus prescribe fiscal consolidation as remedy for the external imbalances [12]. The theoretical and empirical literature is not in unison on this conventional view that budget balance exerts significant influence on the current account balance; hence accounting for the plethora of mixed empirical results on the subject matter. The point of interest with SSA, however, is that in recent times, other key macroeconomic indicators such as inflation and real output growth have posted a positive outlook in contrast to the worsening fiscal and external balances and thus call for closer scrutiny. The objective of the paper is to test the twin deficits hypothesis for SSA using data for 41 countries from 2000 to 2012.

The rest of the paper is organized as follows. The next section provides a survey of the literature, followed by a discussion of the methodology in Section 3. The results and discussion are presented in Section 4. Section 5 concludes with policy recommendations.

\section{Literature Review}

The unmatched increases in the deficits of the U.S. in both current (trade) account balance and fiscal balance, particularly, in the 1980s engineered the theoretical formulation and empirical scrutiny of the twin-deficits hypothesis [13] cited in [14]. In spite of the various arguments and the theoretical explanations espoused on the twin-deficits hypothesis, the evidence as to whether sustained budget deficits impact the current account remains an empirical issue. Over the years, the empirical literature has sought to establish a link between the budget balance and current account balance through country-level, cross-country and regional studies. The outcomes of the available studies are however mixed as some find causal relationship between the budget balance and current account balance whilst others have not. Even for studies that find a causal relationship, there seem to be ambiguity regarding the direction of causation. Some studies find a positive relationship which affirm the twin-deficits hypothesis (Keynesian view) with causality running from the budget balance to the current account balance (see inter alia; [2] [4] [8] [10] [15]-[17]). Other outcomes however support the reverse causality argument (Neoclassical view) that the current account balance affects the budget balance and not vice-versa [1] [18]-[21].

Evidence in both the theoretical and empirical literature although not unanimous, essentially points to a unidirectional causal relationship from the budget balance to the current account balance [2] [4] [8] [10] [15] [17]. Yet, for a panel of South East Asian Central Banks' countries (SEACEN), [22] showed a bi-directional causal relationship between budget deficits and current account deficits for six out of nine SEACEN countries studied. Similarly, [23] and [24] found bi-directional causality between the two variables for the Brazilian and Pakistani economies, respectively.

In the empirical literature, the focus of most studies have been to establish the direction of causality as well as the magnitude or significance of the causal relationship between the fiscal and current account balances. Such studies normally involve panel regressions for a large number of countries as well as time series regressions for individual country analysis. These studies have in the main found statistically significant impact of expansionary fiscal policy actions on external imbalances. Quite recent studies such as [4] argue that changes in fiscal policy are indeed linked with changes in the current account, but then the relationship is far less than one-for-one. The paper's panel analysis of 124 countries reveal that a 1 percentage point of GDP improvement in the fiscal balance is found to enhance the current account balance by $0.2-0.3$ percentage points of GDP upon impact, with 
the effects persisting for a few years. [5] found similar results in their panel analysis of 155 countries, 42 of which are microstates. Their panel regression results show that a percentage point improvement in the fiscal balance improves the current account balance by 0.4 percentage points of GDP.

The literature highlights the importance of country specific features in the determination of long-run causality and significance of the relationship between fiscal and external imbalances. Country-specific characteristics in some cases may account for the lack of unanimity in defining the causal relationship between the two deficits as well as the significance of the long-run causality between the budget deficits and current account deficits. [11] share in this view and argue that the observed cross-country variations with respect to the impact of fiscal deficits on current account deficits show that the dynamic relationship between the two deficits is subject to change depending on the underlying tax system, trade patterns and barriers, monetary regimes, the exchange rate regime and a complex host of internal and international forces that shape a country's economic status in the global economy. The paper confirms the presence and direction of causality between the budget and current account deficits, although the findings are largely country specific and indeterminate in certain cases. Equally, [8] points out that the impact of fiscal shocks on the current account seems to be greater and persisting in economies where total trade as a share of GDP is higher (Canada and the United Kingdom) than in economies where trade is a smaller share of GDP (United States and Australia). The observed differences can be attributed to different levels of integration in global trade by these countries. For relatively more open economies (i.e. economies where the import content of both consumption and investment is high) domestic interest rates are less affected by a fiscal expansion, while an appreciation of the exchange rate increases the real return to investment significantly and thus encourages investment. In relatively closed economies, however, domestic interest rates are more strongly affected by a fiscal expansion coupled with its negative ensuing effect on investments demand, ceteris paribus. Also, [25] found evidence in support of the conventional view for Kenya in a multivariate environment as opposed to directly between budget deficits and current account deficits, using quarterly time series data spanning $1970 Q_{1}-2012 Q_{1}$.

Some empirical outcomes, however, have out rightly rejected the twin-deficits hypothesis, implying no longrun causal relationship between the budget deficits and the current account deficits. For instance, [1] using time series data for Italy from 1970 to 2010, reports Granger-causality tests that show a unidirectional flow from trade deficits to budget deficits but cointegration tests reject the presence of a long-run relationship between these variables. Similarly, [26]-[28] argue in favor of the Ricardian view of no long-run causation between the fiscal and current account balances. Contrary to most empirical findings and theoretical propositions, [29]-[31] found results that suggest a "twin-divergence" rather than a twin-deficit relationship between the fiscal balance and current account balance. For instance, [29] found that a rise in government outlay dampens the current account to GDP ratio and this is the case for both temporary and permanent spending shocks, due to endogenous labour supply. [30] considers fiscal policy in a model where 50 percent of the households consume disposable income in each period. They observe that a partly debt-financed rise in government spending depresses the trade balance by slightly less than 0.2 percentage points after 2 - 3 years. [31] in their study of the U.S. economy, suggests an expansionary fiscal policy shock, or a government budget deficit shock, improves the current account and depreciates the real exchange rate. They observed that increases in private savings and decline in investment may have contributed to the current account improvement while nominal exchange rate depreciation, as opposed to a relative price level change, could have accounted for the real exchange rate depreciation. The "twin-divergence" of fiscal balances and current account balances could also be attributed to the prevalence of output shocks. That is, output shocks more than fiscal shocks appear to drive the divergence between the current account and the fiscal balances [31].

The obvious ambiguity in the empirical literature regarding the relationship between budget deficits and current account deficits require further investigation. This paper aims at providing further evidence on the relationship between budget deficits and current account deficits, particularly in the context of SSA.

\section{Methodology and Data}

\subsection{The Model}

In order to analyze the effect of fiscal balance on the current account balance, a dynamic panel regression model is estimated. The study uses the dynamic panel model in order to account for temporal autocorrelation, reduce the level of potential spurious regression which may lead to inaccurate inferences and inconsistent estimates. 
Besides, a suitable estimation technique should account for the likelihood of country-specific characteristics that are significant for explaining the current account balance but omitted by the model. Hence, the Fixed Effects model ought to be preferred to the Pooled OLS (POLS) and Random Effects [7].

The presence of econometric problems such as endogeneity and persistence ensure that some panel data estimators (POLS, Fixed Effects, and Random Effects) yield inconsistent estimates. The Generalized Method of Moments (GMM-Sys) dynamic panel model accounts for these problems and addresses potential model misspecification to obtain consistent estimates in the presence of endogenous regressors. Even so, the instruments used must be valid in order for the system GMM estimator to give consistent and reliable estimates. Two main tests are therefore conducted to determine the validity of the instruments. Firstly, a Sargan test of over- identifying restrictions which tests the null hypothesis that the over-identifying restrictions are valid would be conducted. Secondly, Arellano-Bond test is used to scrutinize the hypothesis that there exists no serial correlation between the error terms.

Panel regressions (with individual country fixed effects) using annual data from 2000 to 2012 would be used to test the twin-deficits hypothesis (i.e. whether or not there is any significant and robust association between fiscal balances and current account balances) pertaining to SSA. This study employs the Generalized Method of Moments (GMM-Sys) estimation technique and similar model specification employed by [6]. In particular, the study adopts the GMM estimation technique due to its advantages over the fixed effects and random effects models. For instance, the GMM estimation technique in addition to controlling for potential endogeneity also captures unobserved country-specific and time-variant effects. The model to be estimated is formulated as:

$$
C A_{i t}=\alpha_{0}+\alpha_{1} \text { Deficit }_{i t}+\alpha_{2} \text { Govexp }_{i t}+\alpha_{3} Y G_{i t}+\alpha_{4} \text { Debt }_{i t}+\alpha_{5} \text { PopG }_{i t}+v_{i t}
$$

where $C A_{i t}$ measures the external balance for country $i(i=1, \cdots, n)$ at time $t(t=1, \cdots, T)$, Deficit $t_{i t}$ is the government budget deficit, Govexp $p_{i t}$ is government expenditure, $Y G_{i t}$ is the real per capita income growth, $D e b t_{i t}$ is government's debt stock, $P o p G_{i t}$ is annual population growth rate and $V_{i t}$ is the error term.

The empirical approach in equation (1) captures both the Ricardian and Keynesian views. The primary distinction between the Ricardian and the Keynesian theories concerns the sign and significance of $\alpha_{1}$ which is the response of the current account balance to a unit variation in fiscal deficit, ceteris paribus. The conventional Keynesian view suggests that a rise in fiscal deficits tends to deteriorate current account (i.e. $\alpha_{1}<0$ ), whilst private consumption should increase in response to an increase in the fiscal deficit. The Ricardian view suggests that $\alpha_{1}=0$, implying that a unit variation in fiscal deficit does not impact the current account.

\subsection{Data}

Data for the study is sourced from the IMF's World Economic Outlook $\left(C A_{i t}\right.$, Deficit $_{i t}$, Govexp ${ }_{i t}$ and Debt $\left.t_{i t}\right)$ and the World Bank's World Development Indicators $\left(Y G_{i t}\right.$ and $\left.P o p G_{i t}\right)$ online databases. The description of the variables are provided in Table 2.

\section{Results and Discussion}

The descriptive statistics in Table 3 show that the current account deficit as a percentage of GDP averaged 5.5 percent for the 41 SSA countries being studied over the period 2000-2012. The average budget balance stood at -1.5 percent of GDP while government consumption spending posted an average of 26 percent of GDP. Real GDP per capita grew annually at an average of 2.2 percent and the level of public debt in the region averaged 76.2 percent of GDP, an indication of a heavy and unsustainable debt burden on SSA countries. The region's population grew at an annual rate of 2.5 percent over the period (Table 3).

The dynamic panel estimates of the current account model are presented in Table 3. The Wald Chi-squared statistic for all the regressions shows that the explanatory variables are jointly significant. The Arellano-Bond test AR (2) in first differences fails to reject the null hypothesis of no two-period serial correlation in the residuals. Besides, the Sargan test for over-identifying restrictions shows that the over-identifying restrictions are valid in the model; hence the model is not weakened by too many instruments. The data for estimation favors the fixed-effects model which is a requirement for the use of the system GMM estimation procedure. The other diagnostic tests; autocorrelation, heteroscedasticity, and over-identifying restrictions yield favorable results for the use of the system GMM estimation technique (see Appendix Tables A1-A4 for test results) and also underscores the appropriateness of the system GMM estimation technique and the reliability of its estimates. 
Table 2. List of variables.

\begin{tabular}{ccc}
\hline Variable & Description & Source \\
\hline CA & Current Account to GDP ratio & IMF \\
Deficit & Net borrowing $(-)$ or net lending $(+)$ of central government as \% of GDP & IMF \\
Govexp & General government total expenditure as \% of GDP & IMF \\
YG & GDP per capita growth (annual \%) & World Bank \\
Debt & Gross government debt as \% of GDP & IMF \\
PopG & Population growth annual as \% of GDP & World Bank \\
\hline
\end{tabular}

Table 3. Descriptive statistics of variables.

\begin{tabular}{|c|c|c|c|c|}
\hline Variable & Mean & Standard deviation & Minimum & Maximum \\
\hline Current Account \% of GDP & -5.51 & 10.35 & -83.66 & 25.63 \\
\hline Fiscal Deficit \% of GDP & -1.54 & 6.71 & -30.42 & 40.34 \\
\hline Gov. expenditure \% of GDP & 25.66 & 9.75 & 5.62 & 74.16 \\
\hline Real GDP per capita growth & 2.23 & 5.86 & -33.98 & 58.36 \\
\hline Public Debt \% of GDP & 76.24 & 100.46 & 0.78 & 931.66 \\
\hline Population growth rate & 2.52 & 0.86 & 0.11 & 6.68 \\
\hline
\end{tabular}

Source: Authors' computation (based on data from the IMF’s WEO and the World Bank's WDI online databases) using STATA 13.

The coefficient of fiscal deficits in both the static panel and system GMM estimations is positive, indicating that a 1 unit increase in fiscal deficit improves the current account to GDP ratio by 0.39 and 0.35 units respectively. Moreover, the first lag of budget deficit (Deficit ${ }_{i, t-1}$ ) also improves the current account in the system GMM estimation by 0.14 units. This significant positive relationship between the current account and fiscal balance at 1 percent level of significance, implies a rejection of both the twin-deficits hypothesis as well as the Ricardian equivalence arguments, as the former posits widening fiscal deficits is inimical to the current account (a coefficient less than zero) whereas the latter suggests no effect on the current account (a coefficient equal to zero). Our results contradict the outcomes of some very recent cross-country and panel studies on the subject matter in the literature which have variously sought to affirm the twin-deficits hypothesis. For instance, [7] find that a $1 \%$ increase in the budget deficit worsens the current account position by $0.37 \%$ in their study of $33 \mathrm{Eu}-$ ropean countries. Similarly, [2] found that a $1 \%$ rise in the budget deficit deteriorates the current account by $0.47 \%$ which is higher than the $0.3 \%$ and $0.4 \%$ obtained by [4] and [5], respectively. Even so, contrary to the predictions of most theoretical and empirical studies, [31] also found results similar to ours, thereby suggesting a "twin-divergence" rather than a twin-deficits relationship between the fiscal balance and current account balance. In other words, an expansionary fiscal policy shock or a government budget deficit shock tends to improve the current account and depreciates the real exchange rate.

In line with the a priori expectations, the coefficient of government expenditure is negative and significant only in the System GMM estimation. Similarly, the first lag of government spending (Govexp $p_{i, t-1}$ ) deteriorates the current account by 0.12 units. This outcome therefore suggests that a unit increase in government's expenditure worsens the trade balance by 0.11 units and with a lag of 0.12 units, respectively. This result underscores the relevance of the size of government or public spending for trade equilibrium. The system GMM estimates of earlier studies by, for instance, [6] and [7] have found similar results. Economic theory posits that per capita income growth empowers households to demand goods and services including imports and this in turn worsens the trade balance. The system GMM estimates show that income growth deteriorates the current account. The static panel estimation shows a similar outcome, thus confirming the results of [6] and [7] (Table 4)

Our findings regarding public debt are mixed. The coefficient of public debt in the static panel estimation is positive and significant, while in the system GMM estimation it is negative and significant with a two-period lag. The latter outcome is in tune with the $a$ priori expectations and confirms findings from some recent studies (see for instance, [6]). Continued recourse to higher borrowing at very high real interest rates, will over time yield a 
Table 4. Static Panel and system GMM estimation results.

\begin{tabular}{|c|c|c|}
\hline Variables & Static Panel & System GMM \\
\hline Constant & & $\begin{array}{l}-2.6569 \\
(4.4555)\end{array}$ \\
\hline $\mathrm{CA}_{t-1}$ & $\begin{array}{l}-2.7037 \\
(2.6471)\end{array}$ & $\begin{array}{l}0.2134^{* * *} \\
(0.0168)\end{array}$ \\
\hline $\mathrm{CA}_{t-2}$ & & $\begin{array}{c}-0.1175^{* * *} \\
(0.0091)\end{array}$ \\
\hline Deficit $_{t}$ & & $\begin{array}{l}0.3538^{* * *} \\
(0.06080)\end{array}$ \\
\hline Deficit $_{i, t-1}$ & $\begin{array}{c}0.3879^{* * *} \\
(0.0702)\end{array}$ & $\begin{array}{l}0.1425^{* * *} \\
(0.0209)\end{array}$ \\
\hline Deficit $_{i, t-2}$ & & $\begin{array}{l}0.00126 \\
(0.0248)\end{array}$ \\
\hline Govexp $_{t}$ & & $\begin{array}{l}-0.1111^{*} \\
(0.0591)\end{array}$ \\
\hline Govexp $_{i, t-1}$ & $\begin{array}{c}0.0120 \\
(0.0649)\end{array}$ & $\begin{array}{c}-0.1205^{* * *} \\
(0.0244)\end{array}$ \\
\hline $\operatorname{Govexp}_{i, t-2}$ & & $\begin{array}{l}-0.0054 \\
(0.0330)\end{array}$ \\
\hline $\mathrm{YG}_{t}$ & & $\begin{array}{l}-0.0100 \\
(0.0259)\end{array}$ \\
\hline $\mathrm{YG}_{i, t-1}$ & $\begin{array}{c}-0.1623^{* *} \\
(0.0662)\end{array}$ & $\begin{array}{c}-0.1871^{* * *} \\
(0.0327)\end{array}$ \\
\hline $\mathrm{YG}_{i, t-2}$ & & $\begin{array}{c}-0.2761^{* * *} \\
(0.0291)\end{array}$ \\
\hline Debt $_{t}$ & & $\begin{array}{c}0.0044 \\
(0.0066)\end{array}$ \\
\hline $\operatorname{Debt}_{i, t-1}$ & $\begin{array}{c}0.0176^{* * *} \\
(0.0053)\end{array}$ & $\begin{array}{l}-0.0011 \\
(0.0051)\end{array}$ \\
\hline $\operatorname{Debt}_{i, t-2}$ & & $\begin{array}{c}-0.0238^{* * *} \\
(0.0044)\end{array}$ \\
\hline Popg $_{t}$ & & $\begin{array}{c}0.6358 \\
(6.8263)\end{array}$ \\
\hline Popg $_{i, t-1}$ & $\begin{array}{l}-1.4204^{*} \\
(0.7375)\end{array}$ & $\begin{array}{l}-4.8017 \\
(9.3516)\end{array}$ \\
\hline Popg $_{i, t-2}$ & & $\begin{array}{c}6.8567 \\
(4.3872)\end{array}$ \\
\hline Wald chi-squared (Prob > chi-squared) & 0.0000 & 0.0000 \\
\hline Arellano-Bond (AR (2), Prob > Z) & & 0.2407 \\
\hline Sargan test (Prob $>$ Chi-squared) & & 0.6583 \\
\hline No. of observation & 520 & 520 \\
\hline
\end{tabular}

Note: The dependent variable is Current Account to GDP ratio. Figures in parenthesis are the standard errors of the estimates whereas ${ }^{* * *},{ }^{* *}$ and ${ }^{*}$ denote the statistical significance of the estimates at $1 \%, 5 \%$ and $10 \%$ respectively. Source: Authors' Computation Using STATA 13.

rising debt burden that will ultimately constrain borrowing capacity. The effect of population growth on the current account balance is negative and significant in the static panel estimate; indicating that 1 unit increase in population growth worsens the current account by 1.42 units. This finding is also consistent with Magazzino [6].

\section{Conclusion and Policy Implications}

This paper sought to test the twin deficits hypothesis-the relationship between the fiscal balance and the current account balance- - based on SSA data. The twin deficits hypothesis posits that fiscal deficits reflect in current account deficits. The conclusion drawn from the estimation results indicate, however, that fiscal deficits of governments in SSA improve the current account and vice versa, thereby rejecting the twin-deficits hypothesis in favor of the twin divergence proposition. This finding rather paradoxically suggests rising budget deficits could aid the reduction of SSA's external deficits. Such situation could arise during economic downturns, where output falls and the fiscal balance worsens. The current account will most likely improve at the same time if the fall in output leads to a greater fall in investment than the fall in national saving. In relatively open economies such as those of SSA, a fiscal expansion could thus result in an increase in the real interest rate which may in turn crowd out private investment but stimulate private saving. Sticky prices could account for a real exchange 
rate depreciation resulting from a government deficit shock, since nominal exchange rate depreciation (as opposed to a change in the relative price level) may well explain the real exchange rate depreciation [31].

The implication of our findings for policy is that fiscal deficit can be relied upon to improve the current account perhaps only during slumps and interest rate would have to go up to crowd out private investment but stimulate private saving along with a real depreciation of the exchange rate. Since several other factors determine the direction of change of these variables (interest rate and exchange rate, etc.), it will be in the interest of the governments of the region to work at reducing their budget deficits instead since the conditions necessary for the deficits to improve the current account are clearly not under their control. Moreover, fiscal profligacy through unguarded public spending could hurt the external stance of SSA countries. On the contrary, and as our results show, fiscal consolidation could be one of the measures to reduce Sub-Saharan Africa's large current account deficits.

A shortcoming of this paper, however, is the exclusion of variables such as real effective exchange rate, real interest rate, and trade openness (which influence the current account), due to unavailability of consistent data for countries in the study. In addition, net government lending/borrowing as percent of GDP was used as proxy in the absence of data for actual budget deficit to GDP ratio as was similarly employed by [7].

\section{References}

[1] Magazzino, C. (2012) Fiscal Policy, Consumption and Current Account in the European Countries. Economics Bulletin, 32, 1330-1344.

[2] Miteza, I. (2012) Fiscal Deficits, Current Deficits and Investment: A Panel Causality Framework of 20 OECD Countries. Applied Econometrics and International Development, 12, 6-19.

[3] IMF (2013) Regional Economic Outlook for Sub-Saharan Africa. International Monetary Fund, Washington DC.

[4] Abbas, S.M., Bouhga-Hagbe J., Fatás A.J., Mauro, P. and Velloso, R.C. (2010) Fiscal Policy and the Current Account. International Monetary Fund Working Paper WP/10/121.

[5] Endegnanew, Y., Amo-Yartey, C. and Turner-Jones, T. (2012) Fiscal Policy and the Current Account: Are Microstates Different? IMF Working Paper WP/12/51.

[6] Magazzino, C. (2012) The Twin Deficits Phenomenon: Evidence from Italy. Journal of Economic Cooperation and Development, 33, 65-80.

[7] Forte, F. and Magazzino, C. (2013) Twin Deficits in the European Countries. International Advances in Economic Research, 19, 289-310. http://dx.doi.org/10.1007/s11294-013-9406-3

[8] Corsetti, G., Müller, G.J. and Sibert, A. (2006) Twin Deficits: Squaring Theory, Evidence and Common Sense. Economic Policy, 21, 597-638. http://dx.doi.org/10.1111/j.1468-0327.2006.00167.x

[9] Monacelli, T. and Perotti, R. (2008) Openness and the Sectoral Effects of Fiscal Policy. Journal of the European Economic Association, 6, 395-403. http://dx.doi.org/10.1162/JEEA.2008.6.2-3.395

[10] Beetsma, R., Klaassen, F. and Giuliodori, M. (2008) The Effects of Public Spending Shocks on Trade Balances and Budget Deficits in the European Union. Journal of the European Economic Association, 6, 414-423. http://dx.doi.org/10.1162/JEEA.2008.6.2-3.414

[11] Hashemzadeh, N. and Wilson, L. (2006) The Dynamics of Current Account and Budget Deficits in Selected Countries in the Middle East and North Africa. International Research Journal of Finance and Economics, 15, 111-129.

[12] Bartolini, L. and Lahiri, A. (2006) Twin Deficits, Twenty Years Later. Federal Reserve Bank of New York. Current Issues in Economics, 12, 1-7.

[13] Darrat, A.F. (1988) Have large Budget Deficits Caused Rising Trade Deficits? Southern Economic Journal, 54, 879887. http://dx.doi.org/10.2307/1059523

[14] Tang, T.C. (2013) Twin Deficits: An Alternative Framework from General Equilibrium Perspective with U.S. Results. Discussion Paper 41/13, Department of Economics, Monash University, Clayton.

[15] Bernheim, B.D. (1988) Budget Deficits and the Balance of Trade. Tax Policy and the Economy, 2, 1-31. http://dx.doi.org/10.1086/tpe.2.20061771

[16] Leachman, L.L. and Francis, B. (2002) Twin Deficits: Apparition or Reality? Applied Economics, 34, 1121-1132. http://dx.doi.org/10.1080/00036840110069976 
[17] Bagheri, F., Piraee, K. and Keshtkaran, S. (2012) Testing for Twin Deficits and Ricardian Equivalence Hypotheses: Evidence from Iran. Journal of Social and Development Sciences, 3, 77-84.

[18] Anoruo, E. and Ramchander, S. (1998) Current Account and Fiscal Deficits: Evidence from Five Developing Economies of Asia. Journal of Asian Economics, 9, 487-501. http://dx.doi.org/10.1016/S1049-0078(99)80099-2

[19] Bussière, M., Fratzscher, M. and Müller, G.J. (2005) Productivity Shocks, Budget Deficits and the Current Account. European Central Bank. Working Paper Series No. 509.

[20] Onafowora, O.A. and Owoye, O. (2006) An Empirical Investigation of Budget and Trade Deficits: The Case of Nigeria. The Journal of Developing Areas, 39, 153-174. http://dx.doi.org/10.1353/jda.2006.0009

[21] Egwaikhide, F.O., Ayodele, S.O., Oyerani, O.A. and Tchokote, J. (2002) Causality between Budget Deficit and the Current Account Balance in African Countries. West African Journal of Monetary and Economic Integration, 2, 10-41.

[22] Lau, E. and Baharumshah, A.Z. (2006) Twin Deficits Hypothesis in SEACEN Countries: A Panel Data Analysis of Relationships between Public Budget and Current Account Deficits. Applied Econometrics and International Development (AEID), 6, 213-226.

[23] Islam, M.F. (1998) Brazil’s Twin Deficits: An Empirical Examination. Atlantic Economic Journal, 26, 121-128. http://dx.doi.org/10.1007/BF02299354

[24] Mukhtar, T., Zakaria, M. and Ahmed, M. (2007) An Empirical Investigation for the Twin Deficit Hypothesis in Pakistan. Journal of Economic Cooperation, 28, 63-80.

[25] Njoroge, E.K., Kosimbei, G. and Korir, J. (2014) Testing the Twin Hypothesis for Kenya 1970-2012. International Journal of Business and Economic Research, 3, 160-169. http://dx.doi.org/10.11648/j.ijber.20140305.11

[26] Dewald, W.G. and Ulan, M. (1990) The Twin-Deficit Illusion. Cato Journal, 9, 689-707.

[27] Enders, W. and Lee, B.S. (1990) Current Account and Budget Deficits: Twins or Distant Cousins? The Review of Economics and Statistics, 72, 373-381. http://dx.doi.org/10.2307/2109344

[28] Becker, T. (1997) An Investigation of Ricardian Equivalence in a Common Trends Model. Journal of Monetary Economics, 39, 405-431. http://dx.doi.org/10.1016/S0304-3932(97)00023-8

[29] Baxter, M. (1995) International Trade and Business Cycles. NBER Working Papers 5025, National Bureau of Economic Research, Inc.

[30] Erceg C.J., Guerrieri, L. and Gust, C. (2005) Expansionary Fiscal Shocks and the Current Account. International Finance Discussion Papers 825, Board of Governors of the Federal Reserve System, Washington DC.

[31] Kim, S. and Roubini, N. (2008) Twin Deficit or Twin Divergence? Fiscal Policy, Current Account, and Real Exchange Rate in the U.S. Journal of International Economics, 74, 362-383. http://dx.doi.org/10.1016/j.jinteco.2007.05.012 


\section{Appendix}

Table A1. List of the 41 Sub-Saharan Africa countries in the study by region.

\begin{tabular}{cccc}
\hline East Africa & Middle Africa & Southern Africa & West Africa \\
\hline Burundi & Angola & Botswana & Benin \\
Ethiopia & Cameroon & Lesotho & Burkina Faso \\
Eritrea & Chad & Namibia & Cote d'Ivoire \\
Kenya & Central African Rep & South Africa & Gambia, The \\
Madagascar & Comoros & Swaziland & Ghana \\
Malawi & Congo, Dem. Rep. & Zambia & Guinea \\
Mauritius & Congo, Rep. & & Guinea-Bissau \\
Mozambique & Equatorial Guinea & & Liberia \\
Rwanda & Gabon & & Mali \\
Tanzania & & & Niger \\
Uganda & & Nigeria \\
Zimbabwe & & Senegal \\
& & & Sierra Leone \\
& & & Togo \\
& & &
\end{tabular}

Source: Based on United Nation's classification of countries.

Table A2. Breusch-Pagan/Cook-Weisberg test for heteroscedasticity.

$$
\begin{gathered}
\text { Ho: Constant variance } \\
\text { Chi2 }(1)=8.09 \\
\text { Prob }>\text { chi } 2=0.0541
\end{gathered}
$$

Source: Authors’ computation using Stata 13.

Table A3. Hausman test for fixed versus random effects.

Ho: Difference in coefficients not systematic (there is random effect)

$$
\begin{gathered}
\text { Chi2(6) = (b-B) })^{\prime}\left[\left(\mathrm{V} \_b-V \_B\right)^{\wedge}(1)\right](b-B) \\
=34.25
\end{gathered}
$$

Prob $>$ Chi $2=0.0000$

Source: Authors' computation using Stata 13.

\section{Table A4. Durbin-Wu-Hausman (DWH) test for endogeneity.}

\begin{tabular}{cc}
\hline Null Hypothesis & P-value (Prob > Chi2) \\
\hline Deficits uncorrelated with error term & 0.0541 \\
Government expenditure uncorrelated with error term & 0.0541 \\
Income growth uncorrelated with error term & 0.0541 \\
Public debt uncorrelated with error term & 0.0541 \\
\hline
\end{tabular}

Note: The residuals of the variables are predicted and tested for significance after regressing them on all the other exogenous variables. Source: Authors' computation using Stata 13. 


\section{Submit or recommend next manuscript to SCIRP and we will provide best service for you:}

Accepting pre-submission inquiries through Email, Facebook, LinkedIn, Twitter, etc.

A wide selection of journals (inclusive of 9 subjects, more than 200 journals)

Providing 24-hour high-quality service

User-friendly online submission system

Fair and swift peer-review system

Efficient typesetting and proofreading procedure

Display of the result of downloads and visits, as well as the number of cited articles

Maximum dissemination of your research work

Submit your manuscript at: http://papersubmission.scirp.org/ 